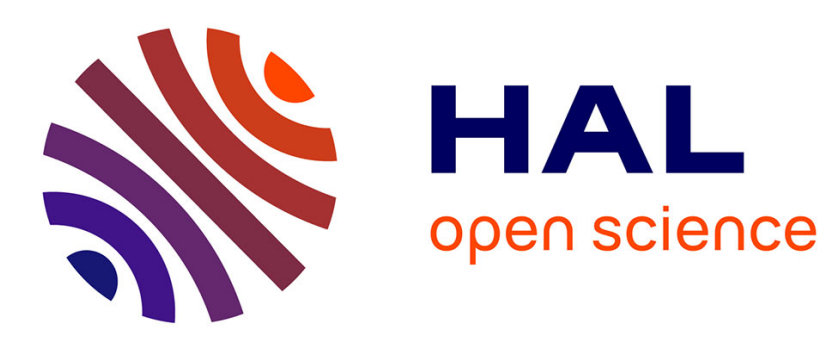

\title{
Asymmetric copper-catalyzed Diels-Alder reaction revisited: control of the structure of bis(oxazoline) ligands
}

\author{
Paul Le Maux, Vincent Dorcet, Gérard Simonneaux
}

\section{- To cite this version:}

Paul Le Maux, Vincent Dorcet, Gérard Simonneaux. Asymmetric copper-catalyzed Diels-Alder reaction revisited: control of the structure of bis(oxazoline) ligands. Tetrahedron, 2013, 69 (38), pp.82918298. 10.1016/j.tet.2013.06.093 . hal-00840883

\section{HAL Id: hal-00840883}

\section{https://hal-univ-rennes1.archives-ouvertes.fr/hal-00840883}

Submitted on 3 Jul 2013

HAL is a multi-disciplinary open access archive for the deposit and dissemination of scientific research documents, whether they are published or not. The documents may come from teaching and research institutions in France or abroad, or from public or private research centers.
L'archive ouverte pluridisciplinaire HAL, est destinée au dépôt et à la diffusion de documents scientifiques de niveau recherche, publiés ou non, émanant des établissements d'enseignement et de recherche français ou étrangers, des laboratoires publics ou privés. 


\title{
Asymmetric copper-catalyzed Diels-Alder reaction revisited: control of the structure of bis(oxazoline) ligands.
}

\author{
Paul Le Maux, ${ }^{\mathrm{a}, *}$ Vincent Dorcet ${ }^{\mathrm{b}}$ and Gérard Simonneaux ${ }^{\mathrm{a}, *}$ \\ Institut des Sciences Chimiques de Rennes, UMR CNRS 6226, ${ }^{a}$ Ingénierie Chimique et \\ Molécules pour le Vivant, and ${ }^{b}$ Centre de Diffractométrie, UMR CNRS 6226, Université de \\ Rennes 1, Campus de Beaulieu, 35042 Rennes Cedex, France
}

\begin{abstract}
Synthesis of 1,4-bis(oxazoline) ligands bearing a bicyclo[2,2,2]backbone derived from 9,10-dihydro-9,10-ethanoanthacene trans-dicarboxylic acid was revisited. Starting from L- or D-amino alcohols and either (S,S) or (R,R)-dihydroethano trans-dicarboxylic acid, a complete series of ligands was evaluated in the copper-catalyzed Diels-Alder reaction. The most efficient ligands with a phenyl substituent on the oxazoline ring afforded enantiomeric excess up to $98 \%$. This is different from previous results indicating that the best enantioselectivity involved a diastereomeric ligand with the meso-backbone.
\end{abstract}

Keywords: Chiral bis(oxazoline) synthesis; Bicyclo[2.2.2] backbone; Diels-Alder catalysis; Copper; Enantioselectivity.

*Corresponding author. E-mail address: paul.lemaux@univ-rennes1.fr (P. Le Maux). 


\section{Introduction}

Chiral bis(oxazoline) ligands have emerged as one class of important and efficient $\mathrm{C}_{2-}$ symmetric ligands in numerous metal-catalyzed asymmetric transformations. ${ }^{1-9}$ Among them, a novel class of oxazoline ligands with multiple elements of chirality has been synthesized from readily available chiral diacid and chiral amino alcohol (Fig. 1). Besides the central chirality element in the oxazoline moiety, these ligands possess an additional chirality element in the backbone such as 1,3-dioxolane $\mathbf{I}^{10-12}$ bicyclo [2,2,1] II, [2,2,2] III, ${ }^{13}$ cyclohexane $\mathbf{I V},{ }^{14,15}$ and cyclopentane $\mathbf{V}{ }^{16}$

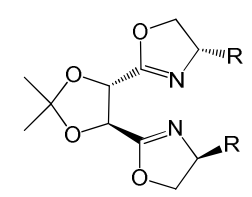

I

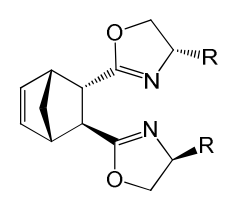

II

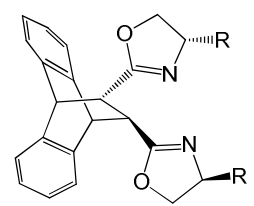

III

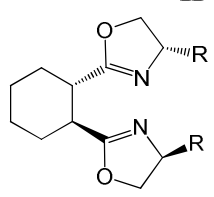

IV

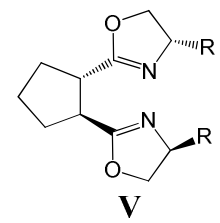

Fig. 1.

Although the Diels-Alder reaction between acrylimide dienophiles and cyclopentadiene was the most successful application of the $\mathrm{Cu}(\mathrm{II})$-bis(oxazoline) catalytic system with enantiomeric excess up to $99 \%,{ }^{17-31}$ its application with the ligands I, II, III, IV and $\mathbf{V}$ was less effective in enantioselectivity. In particular, the ligand III, previously introduced by Takacs et al., ${ }^{13}$ has particularly focused our attention since the best enantioselectivity (75\%) in the Diels-Alder reaction surprisingly involves the meso-backbone and poor results were obtained with the other chiral configurations. Moreover, the authors ${ }^{13}$ indicated that a phenomenon of epimerization was observed during the synthesis of these ligands. These results inspired us to reinvestigate the synthesis of these ligands with more convenient routes to better control the stability of their relative configuration. 
In the present work we revisit this class of bis(oxazoline) ligands in which the two oxazolines are separated by a dihydroethanoanthracene backbone (Figure 1, III). With the goal to rationalize and optimize the results obtained in catalysis, a more convenient preparation of the ligand was first described and the four diastereomers were preparated in pure form. The effect of structure change of the ligands on the stereochemical outcome of the asymmetric copper-catalyzed Diels-Alder reaction between $\mathrm{N}$-acryloyloxazolidinone or $\mathrm{N}$ crotonyloxazolidinone and cyclopentadiene was then fully investigated yielding high enantiomeric excess (up to 98\%). As expected, the best ees were obtained with pure R,R and S,S bis(oxazoline), provided that the chirality of the backbone matched correctly the chirality of the bis(oxazoline).

\section{Results and Discussion}

The bis(oxazoline) ligands were synthesized from the corresponding 9,10-dihydro9,10-ethanoanthacene trans-(11S,12S) and trans-(11R,12R) dicarboxylic acid (1) as shown in Scheme 1. After chiral separation with brucine, ${ }^{32}$ conversion of the diacid into the corresponding acid dichloride by reaction with the oxalyl chloride ${ }^{16}$ was accomplished within $1 \mathrm{~h}$. After removing the solvent and excess oxalyl chloride, the product was used in the next step without purification. Overnight reaction with 2.2 equiv of the amino alcohol in the presence of triethylamine afforded the expected bis-hydroxyamide $\mathbf{3}$ as a white solid in 60$85 \%$ yield. The ${ }^{1} \mathrm{H}$ NMR analysis confirmed the presence of the desired product as a single diastereomer. It should be noted that some epimerization occurs with the previously requisited procedure $^{13}$ in forming the diamide intermediate.

Conversion of bis(hydroxyamide) $\mathbf{3}$ to the corresponding bis(oxazoline) $\mathbf{4}$ was carried out in one step by reaction with diethylaminosulfur trifluoride in $\mathrm{CH}_{2} \mathrm{Cl}_{2}$ at $-78^{\circ} \mathrm{C}$ followed by 
base induced cyclisation ${ }^{16,9}$ in $50-80 \%$ yield. For the ligand $\mathbf{4 d}$, the bis(hydroxyamide) $\mathbf{3 d}$ was first converted into the bis(amide) dichloride with $\mathrm{SOCl}_{2}$ and then the cyclization was achieved with aqueous $\mathrm{NaOH}$ in $73 \%$ yield. The dihydroxyamide 6 with the meso-backbone was synthesized from the anhydride 5 (not the acid) ${ }^{33}$ and the (R)-phenylglycinol in the presence of the coupling reagent $\mathrm{N}$-ethoxycarbonyl-2-ethoxy-1,2-dihydroquinoline (EEDQ) in $77 \%$ yield. $^{34,16}$

The corresponding meso-bis(oxazoline) ligand 7 was prepared using a similar route with diethylaminosulfur trifluoride in $\mathrm{CH}_{2} \mathrm{Cl}_{2}$ at $-78^{\circ} \mathrm{C}$. After purification on column chromatography, the ${ }^{1} \mathrm{H}$ NMR spectrum shows peaks corresponding to ligands $\mathbf{4 a}$ and $\mathbf{4 e}^{\prime}(15 \%)$ due to epimerization (Fig. 2(A)). The ${ }^{1} \mathrm{H}$ NMR analysis confirms the progressive disappearance of 7 after $24 \mathrm{~h}$ (50\%, Fig. 2(B)) and after 48 hours, there is total conversion into the ligands $\mathbf{4 a}$ and $\mathbf{4 e}$ ' in a ratio 53/47 (Fig. 2(C)). 


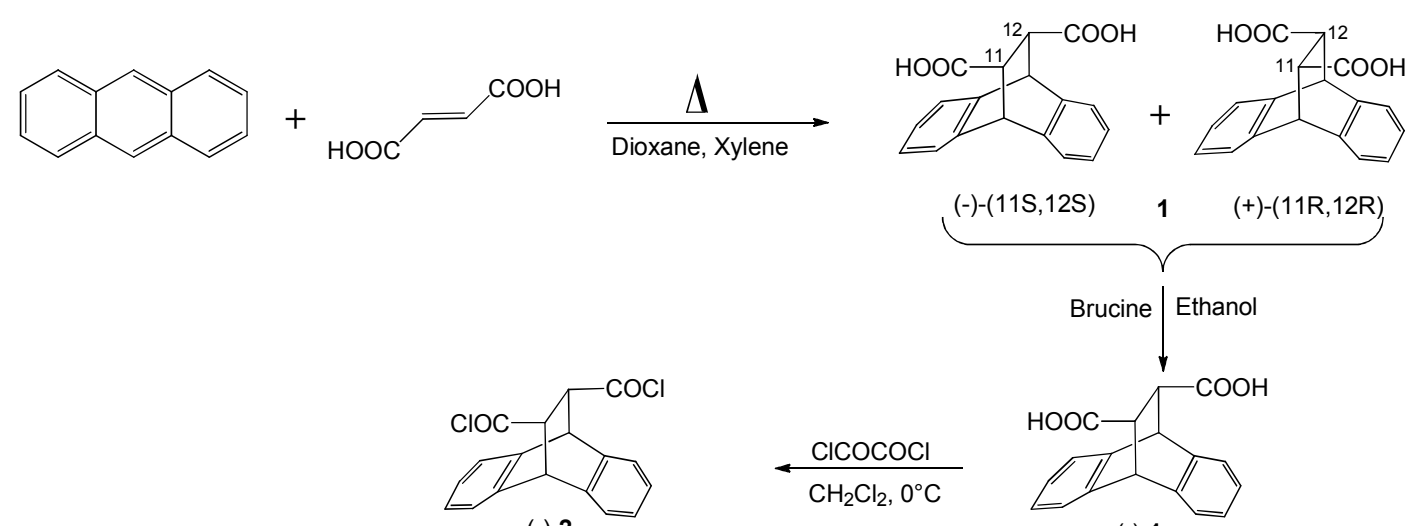

$(-)-2$

$(-)-1$

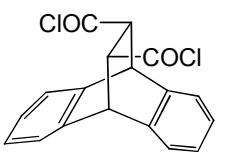

(+)-2

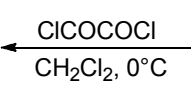

$\mathrm{CH}_{2} \mathrm{Cl}_{2}, 0^{\circ} \mathrm{C}$

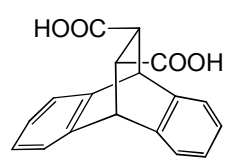

(+)-1

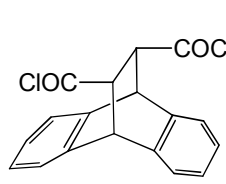

$(-)-2-(11 S, 12 S)$

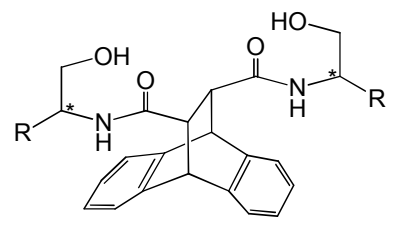

3a $\mathrm{R}=\mathrm{Ph}, \mathrm{C}^{*}(\mathrm{R})$

3a' $\mathrm{R}=\mathrm{Ph}, \mathrm{C}^{*}(\mathrm{~S})$

3b $\mathrm{R}=i-\operatorname{Pr}, \mathrm{C}^{*}(\mathrm{~S})$

3c $\mathrm{R}=t-\mathrm{Bu}, \mathrm{C}^{*}(\mathrm{~S})$

3d $\mathrm{R}=\mathrm{H}$

a) $\mathrm{Et}_{2} \mathrm{NSF}_{3}$ $\frac{\text { b) } \mathrm{K}_{2} \mathrm{CO}_{3}}{\mathrm{CH}_{2} \mathrm{Cl}_{2}-78^{\circ} \mathrm{C}}$

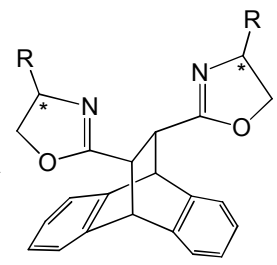

4a $\mathrm{R}=\mathrm{Ph}, \mathrm{C}^{*}(\mathrm{R})$

4a' $\mathrm{R}=\mathrm{Ph}, \mathrm{C}^{*}(\mathrm{~S})$

4b $\mathrm{R}=i-\mathrm{Pr}, \mathrm{C}^{*}(\mathrm{~S})$

4c $\mathrm{R}=t-\mathrm{Bu}, \mathrm{C}^{*}(\mathrm{~S})$

4d $\mathrm{R}=\mathrm{H}$

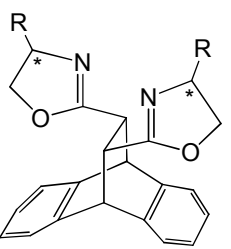

4e $\mathrm{R}=\mathrm{Ph}, \mathrm{C}^{*}(\mathrm{~S})$

$4 \mathrm{e}^{\prime} \quad \mathrm{R}=P h, \mathrm{C}^{*}(\mathrm{R})$

$\operatorname{Racemic}\left\{\begin{array}{l}(-)-2-(11 \mathrm{~S}, 12 \mathrm{~S}) \\ (+)-2-(11 \mathrm{R}, 12 \mathrm{R})\end{array}+(\mathrm{R})-\mathrm{Phenylglycinol} \frac{\mathrm{CH}_{3} \mathrm{~N}}{\mathrm{CH}_{2} \mathrm{Cl}_{2}}\right.$

(THF

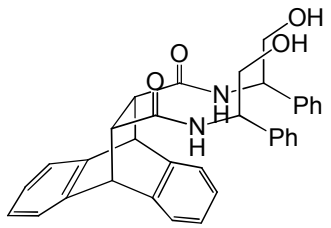

a) $\mathrm{Et}_{2} \mathrm{NSF}_{3}$

$\frac{\text { b) } \mathrm{K}_{2} \mathrm{CO}_{3}}{\mathrm{CH}_{2} \mathrm{Cl}_{2},-78^{\circ} \mathrm{C}}$ 3e $\mathrm{R}=\mathrm{Ph}, \mathrm{C}^{*}(\mathrm{~S})$

3e' $\mathrm{R}=P h, \mathrm{C}^{*}(\mathrm{R})$

.

.



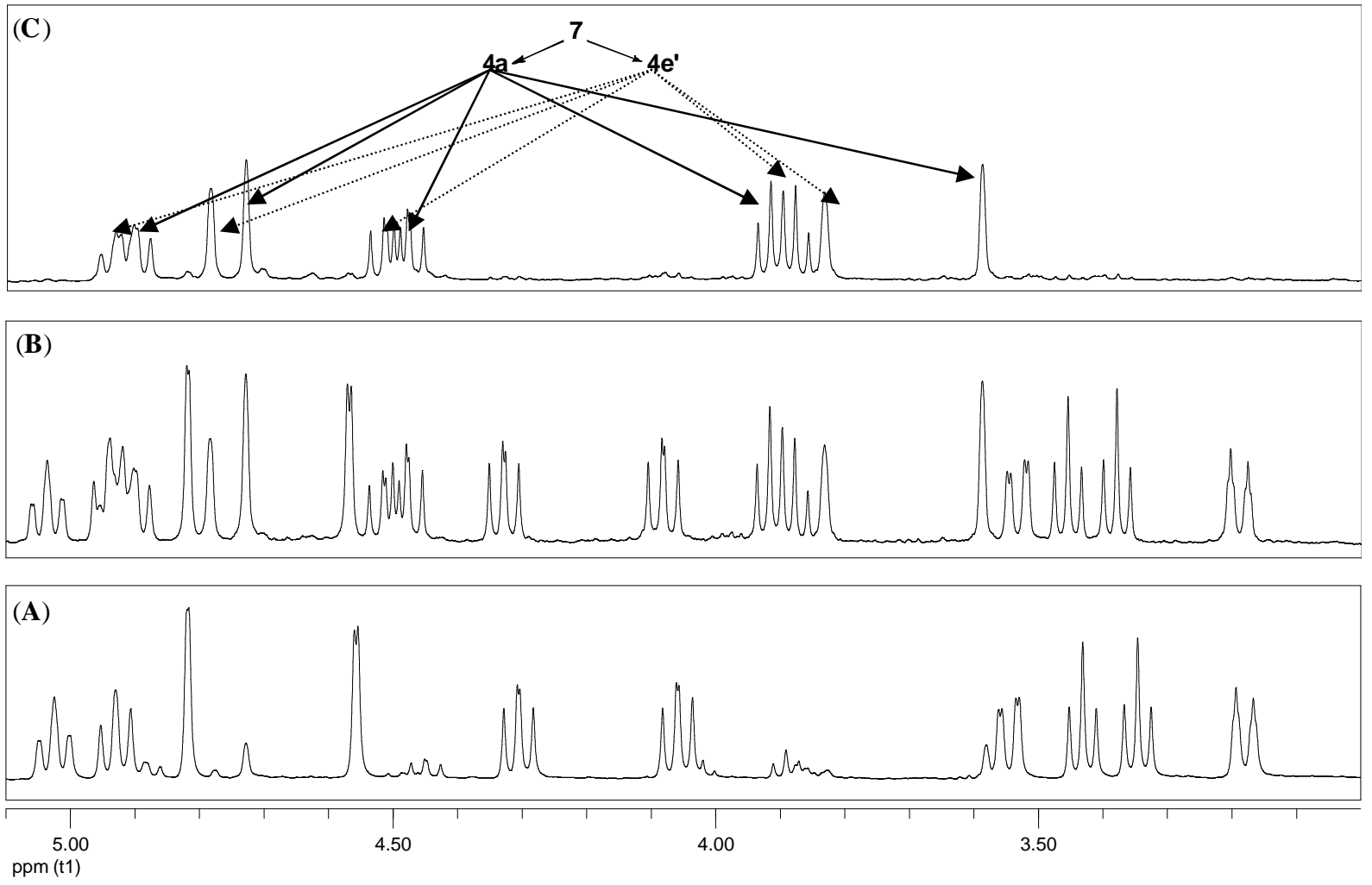

Fig. 2

An X-ray structure of the bis(oxazoline) ligand 4a has been solved (Fig. 3). ${ }^{35}$ X-ray diffraction analysis shows that the two chiral oxazoline rings are slightly twisted pushing the two oxazolinyl phenyl towards the metal centre. In contrast, X-ray structure of the other diastereomer ligand 4e' (using the (R)-phenyl glycinol and trans-(11R,12R)-dicarboxylic acid 1), ${ }^{13}$ showed that the two oxazolinyl phenyl are far away from the metal centre in the complex. 


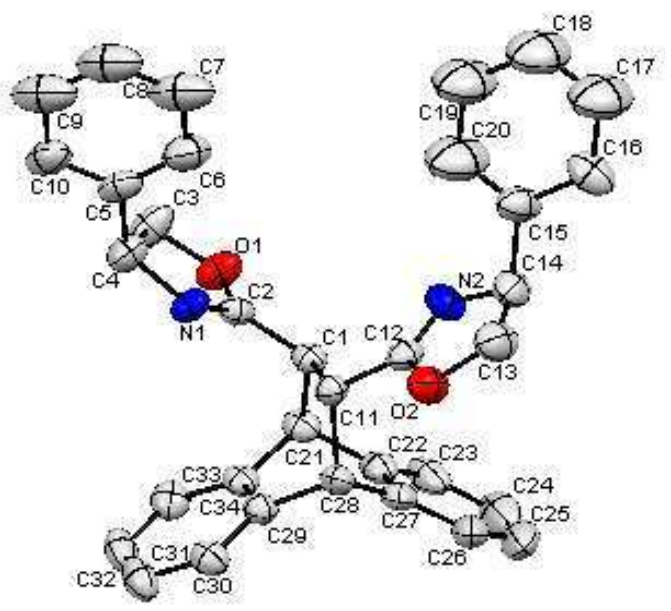

Fig. 3.

The Diels-Alder reaction of $\mathrm{N}$-acryloyloxazolidinone 8a or N-crotonyloxazolidinone $\mathbf{8} \mathbf{b}^{19}$ and cyclopentadiene in the presence of various chiral catalysts derived from the ligands $\mathbf{4}$ and $\mathrm{Cu}(\mathrm{II})$ triflate was then investigated. The catalytic results are summarized in Table 1. 


\section{Table 1.}

Diels-Alder reaction of $\mathbf{8}$ with cyclopentadiene catalyzed by $\mathrm{Cu}(\mathrm{II})(\mathrm{OTf})_{2} /$ bis(oxazoline) complexes $^{\mathrm{a}}$
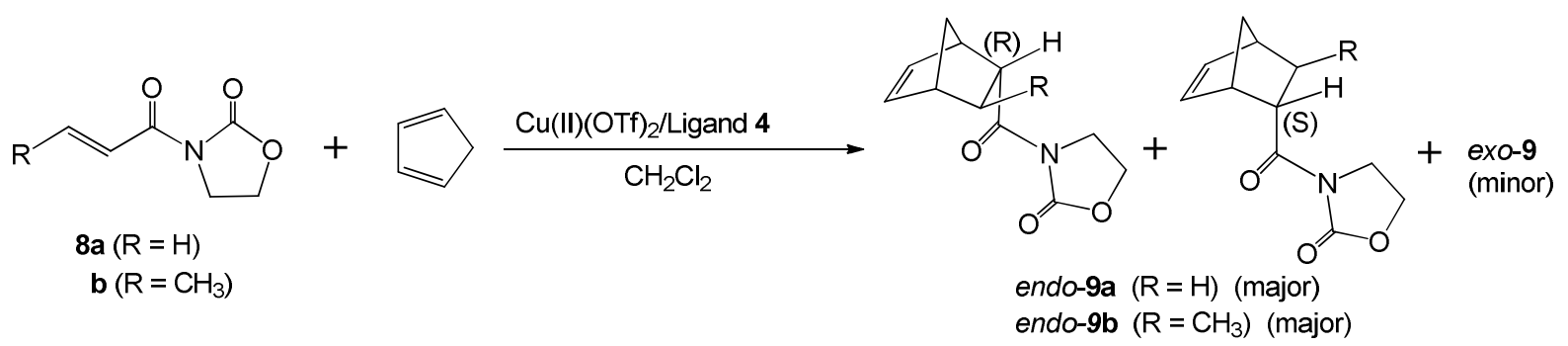

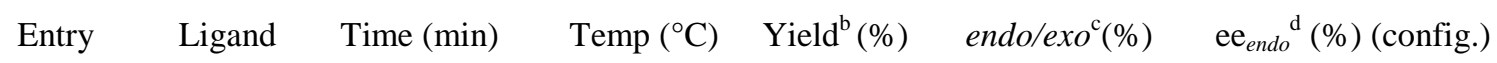

\begin{tabular}{ccccccc}
\hline 1 & $\mathbf{4 a}$ & 5 & 20 & 95 & $94 / 6$ & $93(\mathrm{R})$ \\
2 & $\mathbf{4 a}$ & 10 & 20 & 80 & $75 / 25$ & $21(\mathrm{R})$ \\
3 & $\mathbf{4 b}$ & 30 & 20 & 80 & $85 / 15$ & $16(\mathrm{R})$ \\
4 & $\mathbf{4 c}$ & 240 & 20 & 50 & $88 / 12$ & $10(\mathrm{~S})$ \\
5 & $\mathbf{4 d}$ & 10 & 20 & 80 & $88 / 12$ & $20(\mathrm{R})$ \\
6 & $\mathbf{4 e}$ & 5 & 20 & 95 & $94 / 6$ & $94(\mathrm{~S})$ \\
7 & $\mathbf{4} \mathbf{e}^{\mathrm{f}}$ & 15 & 20 & 82 & $76 / 24$ & $22(\mathrm{~S})$ \\
8 & $\mathbf{4} \mathbf{f}^{\mathrm{e}}$ & 10 & 20 & 80 & $90 / 10$ & $76(\mathrm{R})$ \\
9 & $\mathbf{7}$ & 5 & 20 & 82 & $88 / 12$ & $77(\mathrm{R})$ \\
$10^{\mathrm{f}}$ & $\mathbf{4 a}$ & 240 & 20 & 85 & $93 / 7$ & $89(\mathrm{R})$ \\
11 & $\mathbf{4 a}$ & 5 & 0 & 95 & $96 / 4$ & $95(\mathrm{R})$ \\
12 & $\mathbf{4 a}$ & 30 & -40 & 93 & $98 / 2$ & $98(\mathrm{R})$ \\
13 & $\mathbf{4 e}$ & 5 & 0 & 95 & $96 / 4$ & $96(\mathrm{~S})$ \\
14 & $\mathbf{4 e}$ & 45 & -40 & 92 & $98 / 2$ & $98(\mathrm{~S})$
\end{tabular}

${ }^{\mathrm{a}}$ Molar ratio of metal/ligand/diene/dienophile: 1/1.2/150/50.

${ }^{\mathrm{b}}$ Isolated yield of cycloadducts after silica gel chromatography.

${ }^{\mathrm{c}}$ Determined by ${ }^{1} \mathrm{H}$ NMR and HPLC.

${ }^{\mathrm{d}}$ Determined by chiral HPLC (Chiralcel OD-H column) and comparison of known optical rotation.

${ }^{\mathrm{e}}$ Ligand prepared from the racemic trans-dicarboxylic acid $\mathbf{1}$ and (-)-(R)- phenylglycinol.

${ }^{\mathrm{f}} \mathrm{N}$-crotonyloxazolidinone as dienophile.

From the results of Table 1 , it is shown that the ligands $\mathbf{4 a}$ and $\mathbf{4 e}$ with the phenyl substituted oxazoline gave the best ee (93-94\%) and endo/exo diastereoselectivity (94/6) (entries 1 and 6). With the ligand $\mathbf{4 a}^{\prime}$ or $\mathbf{4} \mathbf{e}^{\mathbf{\prime}}$, in which the chirality of the oxazoline ring has 
been inverted, the ee was decreased (21\%), as well as the diastereoselectivity (75/25) (entries 2 and 7). The ligands with $i$-Pr $\mathbf{4 b}$ and $t$-Bu $\mathbf{4 c}$ gave low ee (<20\%) (entries 3 and 4). The high reactivity of the catalyst leads to short reaction times $(5-10 \mathrm{mn})$ with yields in the range $80-95 \%$, excepted for the bulky $t$-Bu group (50\% yield) in which a longer reaction time was necessary (4 hours). We also decided to test $\mathrm{N}$-crotonyloxazolidinone $\mathbf{8 b}$ as a substrate to compare our results with those previously reported. ${ }^{13}$ In our hands, the endo-cycloadduct 9 was obtained with $89 \%$ ee and $\mathrm{R}$ configuration, using $\mathbf{4 a}$ as ligand (entry 10), whereas it was previously reported ${ }^{13}$ an enantiomeric excess of $28 \%$ with $\mathrm{S}$ configuration in a similar situation.

The effect of temperature was studied with ligands $\mathbf{4 a}$ and $\mathbf{4 e}$. The highest ee and diastereoselectivity was obtained at $-40^{\circ} \mathrm{C}(98 \%$ and 98/2 respectively) (entries 12 and 14).

The influence of substitution both on the oxazoline ring and on the backbone moiety has been investigated with the goal of better understanding the stereocontrol of the $\mathrm{Cu}(\mathrm{II})$ catalyzed reaction. According to the structure (Fig. 3), we have prepared and tested the four diastereomeric ligands 4 with the phenyl group on the oxazoline ring (as represented in Fig. 4). By changing combination of the enantiomers derived from (+) or (-)-trans-dicarboxylic acid and aminoalcohol, the stereochemistry of the four asymmetric centres can be adjustable. There are two sets of enantiomer pairs corresponding to the ligands $\mathbf{4 a}, \mathbf{4 e}$ and $\mathbf{4} \mathbf{a}^{\prime}, \mathbf{4} \mathbf{e}^{\mathbf{\prime}}$. The two phenyl groups on the oxazoline ring of ligand $\mathbf{4 a}$ and $4 \mathbf{e}$ are placed nearer to the reaction centre than those of $\mathbf{4} \mathbf{a}^{\prime}$ and $\mathbf{4} \mathbf{e}^{\prime}$, and consequently, have a larger effect on the enantioselectivity (93\% versus $21 \%$ ). These results show that the degree of asymmetric induction depends of the chirality on the oxazoline ring in $\mathbf{4 a}$ and $4 \mathbf{a}^{\prime}$ or $\mathbf{4 e}$ and $\mathbf{4} \mathbf{e}^{\prime}$. Furthermore, with the ligands $4 \mathbf{a}$ and $\mathbf{4 a}$ ' or $4 \mathbf{e}$ and $4 \mathbf{e}^{\prime}$, the same endo-9(R) or $9(\mathrm{~S})$ cycloadduct was obtained. The sense of asymmetric induction was logically inverted with the 
enantiomeric ligands $\mathbf{4 a}$ and $\mathbf{4 e}$ or $\mathbf{4} \mathbf{a}^{\prime}$ and $\mathbf{4} \mathbf{e}^{\prime}$ but also with the ligands $\mathbf{4 a}$ and $\mathbf{4} \mathbf{e}^{\mathbf{\prime}}$ or $\mathbf{4 a} \mathbf{a}^{\prime}$ and 4e. These results demonstrate that the chiral sense of enantioselection was determined by the chirality of the backbone. To complete the study, it was also noted that ligand $\mathbf{4 d}$ with no substituent on the oxazoline ring gave an enantioselectivity of $20 \%$ (entry 5). This value was similar to the enantioselectivity obtained with ligand $\mathbf{4} \mathbf{a}^{\prime}$ (entry 2).

In our hands, the ligand 7 gave an ee $=77 \%$ for endo-9 (R)-cycloadduct (entry 9). Actually, this value is very close to that obtained with the ligand $\mathbf{4 f}$ derived from the racemic trans-dicarboxylic acid 1 and (-)-(R)-phenylglycinol, ee $=76 \%$ endo-9(R)-cycloadduct (entry 8). Taking into account the epimerization observed in the NMR study, an epimerization of the ligand 7 may also occur in the catalytic conditions. Since the epimerization is time dependent, a study of the ee obtained using ligand 7 over the time course of the catalytic reaction might be necessary. However, the short time of the catalytic reaction $(<5 \mathrm{~min})$ makes this study too difficult. It should be noted that previous results ${ }^{13}$ gave an ee of $75 \%$ for endo-9(R)cycloadduct, quite similar to our results (77\% ee).

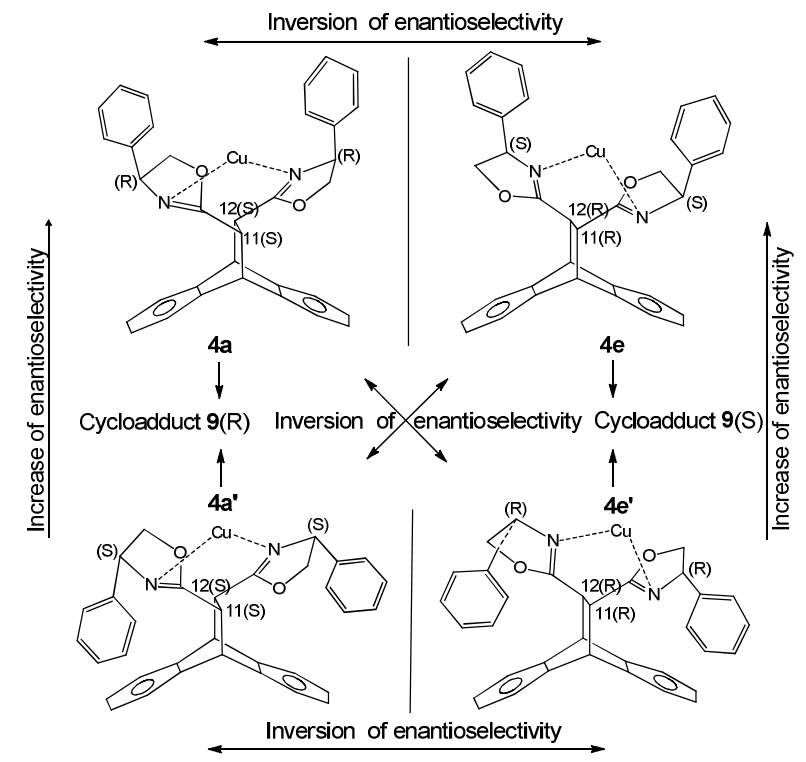

Fig. 4. 


\section{Conclusion}

In conclusion, the synthesis of bis(oxazoline) ligands with four asymmetric centres by combination of the two chiral sources derived from the dihydroethanoanthracene diacid and aminoacids are revisited, and well-structured chiral ligands have been isolated and characterized. The copper-catalyzed asymmetric Diels-Alder reaction between Nacryloyloxazolidinone and N-crotonyloxazolidinone with cyclopentadiene was carried out with these chiral ligands. The best adapted combination for the ligands $\mathbf{4 a}$ and $\mathbf{4 e}$ gave ees up to $98 \%$ at $-40^{\circ} \mathrm{C}$. Studies on the potential of these ligands for other metal-catalyzed asymmetric reactions are now in progress.

\section{Experimental}

\subsection{General}

All reactions were performed under argon. Solvent was distilled from appropriate drying agent, $\mathrm{CH}_{2} \mathrm{Cl}_{2}$ from $\mathrm{CaH}_{2}$. Commercially available reagents were used without further purification unless otherwise stated. All reactions were monitored by TLC with Merck precoated aluminium foil sheets (silica gel 60 with fluorescent indicator $\mathrm{UV}_{254}$ ). Column chromatographies were carried out using silica gel from Acros (0.063-0.200 mm). Melting points were measured on a banc Kofler. ${ }^{1} \mathrm{H}$ NMR and ${ }^{13} \mathrm{C} \mathrm{NMR}$ in $\mathrm{CDCl}_{3}$ were recorded using Bruker (Advance 400dpx) spectrometer at 400 and $100 \mathrm{MHz}$ respectively.The following abbreviations are used in connexion with NMR; s=singlet, $\mathrm{d}=$ doublet, $\mathrm{t}=$ triplet, $\mathrm{q}=\mathrm{quartet}$ and $\mathrm{m}=$ multiplet. Chiral HPLC analysis was performed on a Varian Prostar 218 system equipped with a Chiralcel OD-H column. Optical rotations were recorded with a Perkin-Elmer 341 polarimeter. High resolution mass spectra were performed by the Centre Regional de Mesures Physiques de l'Ouest (CRMPO) at Rennes, France, on a Q-Tof2 spectrometer in ESI positif mode. 
4.2. General procedure of preparation of bis-hydroxyamides 3a, 3a', 3b, 3c, 3d, 3e, 3e', 3f and 6

Oxalyl chloride (3 equiv) was added dropwise to a cooled suspension $\left(0^{\circ} \mathrm{C}\right)$ of the transdiacide (-)-1 or (+)-1 and dimethylformamide (15 mol \%) in $\mathrm{CH}_{2} \mathrm{Cl}_{2}(5 \mathrm{~mL} / \mathrm{mmol})$ under argon. The reaction mixture was stirred at room temperature for $2 \mathrm{~h}$ to give a yellow solution of the trans-diacide chloride (-)-2 or (+)-2. The solvent and excess oxalyl chloride were removed in high vacuum, the residue was taken up in $\mathrm{CH}_{2} \mathrm{Cl}_{2}(4 \mathrm{~mL} / \mathrm{mmol})$ and added slowly to a cold solution $\left(0^{\circ} \mathrm{C}\right)$ of the corresponding amino alcohol (2.2 equiv) and $\mathrm{Et}_{3} \mathrm{~N}$ (5 equiv) in $\mathrm{CH}_{2} \mathrm{Cl}_{2}(2 \mathrm{~mL} / \mathrm{mmol})$ under argon. Stirring was continued for $16 \mathrm{~h}$ at room temperature. After evaporation, the crude product was purified by column chromatography (Hexane-EtOAc$\mathrm{MeOH})$.

4.2.1. (11S,12S)-Bis[(2'-hydroxy-1'-(R)-phenylethyl)]-amido-9,10-dihydro-9,10ethanoanthacene $3 \mathbf{a}$

The product was synthesized according to the general procedure described above from 9,10dihydro-9,10-ethanoanthacene trans-(11S,12S)-dicarboxylic acid 1 (0.5 g,1.7 mmol) and (-)(R)- phenylglycinol (0.65 g, $3.74 \mathrm{mmol}$ ). Purification by column chromatography (hexaneEtOAc, 1:9) yielded a white solid $(840 \mathrm{mg}, 93 \%)$ : m.p. $=147-148{ }^{\circ} \mathrm{C} ;[\alpha]_{\mathrm{D}}{ }^{20}=-34(c 1.44$, $\left.\mathrm{CHCl}_{3}\right) ;{ }^{1} \mathrm{H} \mathrm{NMR}(400 \mathrm{MHz}, \mathrm{CDCl} 3): \delta=2.91(\mathrm{~s}, 2 \mathrm{H}), 3.66(\mathrm{br} \mathrm{s}, 4 \mathrm{H}), 4.59(\mathrm{~s}, 2 \mathrm{H}), 4.90(\mathrm{br}$ s, $2 \mathrm{H}), 7.06-7.32(\mathrm{~m}, 18 \mathrm{H}) ;{ }^{13} \mathrm{C} \mathrm{NMR}\left(100 \mathrm{MHz}, \mathrm{CDCl}_{3}\right): \delta=46.8,49.6,55.8,66.07,123.4$, 125.4, 126.3, 126.7, 127.6, 128.6, 138.8, 140.1, 143.0, 173.5; HRMS [ESI]: $\mathrm{m} / \mathrm{z}$ calcd for $\mathrm{C}_{34} \mathrm{H}_{32} \mathrm{~N}_{2} \mathrm{O}_{4} \mathrm{Na}: 555.2259(\mathrm{M}+\mathrm{Na})^{+}$, found: 555.2255 .

4.2.2.

(11S,12S)-Bis[(2'-hydroxy-1'-(S)-phenylethyl)]-amido-9,10-dihydro-9,10ethanoanthacene $3 \mathbf{a}^{\prime}$ 
The product was synthesized according to the general procedure described above from 9,10dihydro-9,10-ethanoanthacene trans-(11S,12S)-dicarboxylic acid 1 (0.5 g,1.7 mmol) and (+)(S)- phenylglycinol (0.65 g, $3.74 \mathrm{mmol})$. Purification by column chromatography (EtOAc$\mathrm{MeOH}, 0: 1)$ yielded a white solid $(720 \mathrm{mg}, 80 \%)$ : m.p. $=174{ }^{\circ} \mathrm{C}:[\alpha]_{\mathrm{D}}{ }^{20}=+32(c 0.84$, $\left.\mathrm{CHCl}_{3}\right) ;{ }^{1} \mathrm{H} \mathrm{NMR}(400 \mathrm{MHz}, \mathrm{CDCl} 3): \delta=2.96(\mathrm{~s}, 2 \mathrm{H}), 3.68(\mathrm{dd}, \mathrm{J}=6.4,11.6 \mathrm{~Hz}, 2 \mathrm{H}), 3.73$ (dd, J = 3.6, 11.4 Hz, 2H), $4.59(\mathrm{~s}, 2 \mathrm{H}), 4.90(\mathrm{dd}, \mathrm{J}=7.2,11.2 \mathrm{~Hz}, 2 \mathrm{H}), 7.00-7.04(\mathrm{~m}, 6 \mathrm{H})$, 7.16-7.22 (m, 8H), 7.28, $7.58(2 \mathrm{~d}, \mathrm{~J}=8 \mathrm{~Hz}, 4 \mathrm{H}) ;{ }^{13} \mathrm{C} \mathrm{NMR}\left(100 \mathrm{MHz}, \mathrm{CDCl}_{3}\right): \delta=45.9$, 48.9, 56.2, 65.6, 123.4, 125.3, 125.9, 126.7, 127.3, 128.4, 139.6, 140.4, 143.3, 173.5; HRMS [ESI]: $m / z$ calcd for $\mathrm{C}_{34} \mathrm{H}_{32} \mathrm{~N}_{2} \mathrm{O}_{4} \mathrm{Na}: 555.2259(\mathrm{M}+\mathrm{Na})^{+}$, found: 555.2255.

4.2.3. (11S,12S)-Bis[(2'-hydroxy-1'-(S)-isopropylethyl)]-amido-9,10-dihydro-9,10ethanoanthacene $3 b$

The product was synthesized according to the general procedure described above from 9,10dihydro-9,10-ethanoanthacene trans-(11S,12S)-dicarboxylic acid 1 (0.5 g,1.7 mmol) and (+)L-Leucinol (0.438 g, $3.74 \mathrm{mmol}$ ). Purification by column chromatography (hexane-EtOAc, 9:1) yielded a white solid (635 mg, 80\%): m.p. $=134-135{ }^{\circ} \mathrm{C} ;[\alpha]_{\mathrm{D}}{ }^{20}=-18\left(c 0.55, \mathrm{CHCl}_{3}\right)$; ${ }^{1} \mathrm{H}$ NMR (400 MHz , CDCl3): $\delta=0.78,0.80(2 \mathrm{~d}, \mathrm{~J}=6.4 \mathrm{~Hz}, 12 \mathrm{H}), 1.09-1.16,1.22-1.29$ (2m, 4H), 1.39-1.47 (m, 2H), $2.88(\mathrm{~s}, 2 \mathrm{H}), 3.23(\mathrm{dd}, \mathrm{J}=6.8,11.4 \mathrm{~Hz}, 2 \mathrm{H}), 3.46(\mathrm{dd}, \mathrm{J}=3.6,11.6$ $\mathrm{Hz}, 2 \mathrm{H}), 3.85$ (br s, 2H), $4.46(\mathrm{~s}, 2 \mathrm{H}), 7.00-7.06(\mathrm{~m}, 4 \mathrm{H}), 7.21,7.24(2 \mathrm{~d}, \mathrm{~J}=6.8 \mathrm{~Hz}, 4 \mathrm{H}) ;{ }^{13} \mathrm{C}$ $\mathrm{NMR}\left(100 \mathrm{MHz}, \mathrm{CDCl}_{3}\right): \delta=22.0,23.2,24.8,40.2,46.9,49.6,65.4$, , 123.2, 125.4, 126.21, 140.3, 143.2, 173.8; HRMS [ESI]: $m / z$ calcd for $\mathrm{C}_{30} \mathrm{H}_{40} \mathrm{~N}_{2} \mathrm{O}_{4} \mathrm{Na}: 515.2885(\mathrm{M}+\mathrm{Na})^{+}$, found: 515.2883

4.2.4. (11S,12S)-Bis[(2'-hydroxy-1'-(S)-tert-butylethyl)]-amido-9,10-dihydro-9,10ethanoanthacene $3 c$ 
The product was synthesized according to the general procedure described above from 9,10dihydro-9,10-ethanoanthacene trans-(11S,12S)-dicarboxylic acid 1 (1.0 g, $3.4 \mathrm{mmol})$ and (+)(S)-tert-Leucinol (0.876 g, $7.48 \mathrm{mmol})$. Purification by column chromatography (EtOAc:MeOH, 4:1) yielded a white solid (1.27 g, 77\%): m.p. $=220{ }^{\circ} \mathrm{C} ;[\alpha]_{365}{ }^{20}=+57(c 0.95$ , $\left.\mathrm{CHCl}_{3}\right) ;{ }^{1} \mathrm{H} \mathrm{NMR}\left(400 \mathrm{MHz}, \mathrm{CDCl}_{3}\right): \delta=2.90(\mathrm{~s}, 2 \mathrm{H}), 2.92(\mathrm{t}, \mathrm{J}=6.8 \mathrm{~Hz}, 2 \mathrm{H}), 3.36-3.43$ (m, 2H), 3.73-3.79 (m, 4H), $4.62(\mathrm{~s}, 2 \mathrm{H}), 7.10-7.17(\mathrm{~m}, 4 \mathrm{H}), 7.28,7.42(2 \mathrm{~d}, \mathrm{~J}=6.4 \mathrm{~Hz}, 4 \mathrm{H})$;

${ }^{13} \mathrm{C}$ NMR $\left(100 \mathrm{MHz}, \mathrm{CDCl}_{3}\right): \delta=26.8,33.5,46.3,50.5,59.6,62.4$, , 123.2, 125.7, 126.3, 126.4, 140.2, 143.4, 174.7; HRMS [ESI]: $m / z$ calcd for $\mathrm{C}_{30} \mathrm{H}_{40} \mathrm{~N}_{2} \mathrm{O}_{4} \mathrm{Na}: 515.2885(\mathrm{M}+\mathrm{Na})^{+}$, found: 515.2887 .

\subsection{5. (11S,12S)-Bis[(2'-hydroxy-ethyl)]-amido-9,10-dihydro-9,10-ethanoanthacene 3d}

The product was synthesized according to the general procedure described above from 9,10dihydro-9,10-ethanoanthacene trans-(11S,12S)-dicarboxylic acid 1 (1 g, $3.40 \mathrm{mmol})$, and ethanolamine $(0.457 \mathrm{~g}, 7.48 \mathrm{mmol})$ in THF $(5 \mathrm{ml} / \mathrm{mmol})$. Recrystallization from methanol yielded a white solid $(578 \mathrm{mg}, 45 \%)$ : m.p. $=262{ }^{\circ} \mathrm{C} ;[\alpha]_{\mathrm{D}}{ }^{20}=+40\left(c 2.25, \mathrm{CH}_{3} \mathrm{OH}\right) ;{ }^{1} \mathrm{H} \mathrm{NMR}$ $\left(400 \mathrm{MHz}, \mathrm{CD}_{3} \mathrm{OD}\right): \delta=3.28-3.33(\mathrm{~m}, 6 \mathrm{H}), 3.56(\mathrm{t}, \mathrm{J}=6 \mathrm{~Hz}, 4 \mathrm{H}), 4.60(\mathrm{~s}, 2 \mathrm{H}), 7.09$ (quintuplet, $\mathrm{J}=7.2 \mathrm{~Hz}, 4 \mathrm{H}), 7.24(\mathrm{~d}, \mathrm{~J}=6.8 \mathrm{~Hz}, 2 \mathrm{H}), 7.35(\mathrm{~d}, \mathrm{~J}=6.4 \mathrm{~Hz}, 2 \mathrm{H}) ;{ }^{13} \mathrm{C} \mathrm{NMR}(100$ $\left.\mathrm{MHz}, \mathrm{CD}_{3} \mathrm{OD}\right): \delta=40.9,46.5,59.7,122.0,123.8,124.9,139.1,141.7,172.6$; HRMS [ESI]: $m / z$ calcd for $\mathrm{C}_{22} \mathrm{H}_{24} \mathrm{~N}_{2} \mathrm{O}_{4} \mathrm{Na}: 403.1633(\mathrm{M}+\mathrm{Na})^{+}$, found: 403.1633 .

4.2.6. (11R,12R)-Bis[(2'-hydroxy-1'-(S)-phenylethyl)]-amido-9,10-dihydro-9,10ethanoanthacene $3 e$

The product was synthesized according to the general procedure described above from 9,10dihydro-9,10-ethanoanthacene trans-(11R,12R)-dicarboxylic acid $\mathbf{1}(0.5 \mathrm{~g}, 1.7 \mathrm{mmol})$ and (+)(S)- phenylglycinol (0.65 g, $3.74 \mathrm{mmol})$. Purification by column chromatography (hexaneEtOAc, 1:9) yielded a white solid $(820 \mathrm{mg}, 91 \%)$ : m.p. $=137-138{ }^{\circ} \mathrm{C} ;[\alpha]_{\mathrm{D}}{ }^{20}=+30(c 0.51$, 
$\left.\mathrm{CHCl}_{3}\right) ;{ }^{1} \mathrm{H} \mathrm{NMR}(400 \mathrm{MHz}, \mathrm{CDCl} 3): \delta=2.92(\mathrm{~s}, 2 \mathrm{H}), 3.64(\mathrm{~m}, 4 \mathrm{H}), 4.58(\mathrm{~s}, 2 \mathrm{H}), 4.89(\mathrm{dd}$, $\mathrm{J}=5.0,11.8 \mathrm{~Hz}, 2 \mathrm{H}), 7.04-7.30(\mathrm{~m}, 18 \mathrm{H}) ;{ }^{13} \mathrm{C} \mathrm{NMR}\left(100 \mathrm{MHz}, \mathrm{CDCl}_{3}\right): \delta=46.1,50.1,55.8$, $66.7,123.5,125.5,126.5,126.6,127.8,128.8,138.5,140.0,143.0,173.6 ;$ HRMS [ESI]: $m / z$ calcd for $\mathrm{C}_{34} \mathrm{H}_{32} \mathrm{~N}_{2} \mathrm{O}_{4} \mathrm{Na}: 555.2259(\mathrm{M}+\mathrm{Na})^{+}$, found: 555.2255 .

4.2.7. (11R,12R)-Bis[(2'-hydroxy-1'-(R)-phenylethyl)]-amido-9,10-dihydro-9,10ethanoanthacene $3 \mathrm{e}^{\prime}$

The product was synthesized according to the general procedure described above from 9,10dihydro-9,10-ethanoanthacene trans-(11R,12R)-dicarboxylic acid 1 (0.5 g,1.7 mmol) and (-)(R)- phenylglycinol $(0.65 \mathrm{~g}, 3.74 \mathrm{mmol})$. A white precipitate was formed in the solution and it was filtered, washed with $\mathrm{CH}_{2} \mathrm{CL}_{2}$ and dried in vacuum to provide the corresponding bis(hydroxyamide) $(768 \mathrm{mg}, 85 \%):$ m.p. $=148-150{ }^{\circ} \mathrm{C} ;[\alpha]_{\mathrm{D}}{ }^{20}=-31\left(c 0.71, \mathrm{CHCl}_{3}\right) ;{ }^{1} \mathrm{H} \mathrm{NMR}$ (400 MHz, $\mathrm{CDCl} 3): \delta=3.19(\mathrm{~s}, 2 \mathrm{H}), 3.75(\mathrm{br} \mathrm{s}, 4 \mathrm{H}), 4.69$ (s, 2H), 4.95 (br d, 2H), $7.02(\mathrm{dd}, \mathrm{J}$ $=4.0,8.4 \mathrm{~Hz}, 2 \mathrm{H}), 7.19-7.31(\mathrm{~m}, 14 \mathrm{H}), 7.90(\mathrm{~d}, \mathrm{~J}=7.2 \mathrm{~Hz}, 2 \mathrm{H}) ;{ }^{13} \mathrm{C} \mathrm{NMR}(100 \mathrm{MHz}$, $\left.\mathrm{CDCl}_{3}\right): \delta=46.7,49.3,56.1,65.7,123.4,125.4,126.0,126.0,126.7,128.5,139.4,140.4$, 143.3, 173.5; HRMS [ESI]: $m / z$ calcd for $\mathrm{C}_{34} \mathrm{H}_{32} \mathrm{~N}_{2} \mathrm{O}_{4} \mathrm{Na}: 555.2259(\mathrm{M}+\mathrm{Na})^{+}$, found: 555.2255 .

\subsection{8. (11S,12S+11R,12R)-Bis[(2'-hydroxy-1'-(R)-phenylethyl)]-amido-9,10-dihydro-}

\section{9,10-ethanoanthacene $3 f$}

The product was synthesized according to the general procedure described above from racemic- 9,10-dihydro-9,10-ethanoanthacene trans-dicarboxylic acid 1 (0.5 g,1.7 mmol) and (-)-(R)- phenylglycinol (0.65 g, $3.74 \mathrm{mmol})$. Purification by column chromatography (EtOAc), yielded a white solid $(690 \mathrm{mg}, 76 \%): \mathrm{m} . \mathrm{p} .=150{ }^{\circ} \mathrm{C} ;[\alpha]_{589}{ }^{20}=-33\left(\mathrm{c} 1.94, \mathrm{CHCl}_{3}\right)$; ${ }^{1} \mathrm{H}$ NMR $(400 \mathrm{MHz}, \mathrm{CDCl} 3): \delta=3.08(\mathrm{~s}, 2 \mathrm{H}), 3.66(\mathrm{br} \mathrm{s}, 4 \mathrm{H}), 4.60(\mathrm{~s}, 2 \mathrm{H}), 4.87$ (br s, 2H), 6.93-7.22 (m, 16H), $7.77(\mathrm{~d}, \mathrm{~J}=7.2 \mathrm{~Hz}, 2 \mathrm{H}) ;{ }^{13} \mathrm{C} \mathrm{NMR}\left(100 \mathrm{MHz}, \mathrm{CDCl}_{3}\right): \delta=45.9,49.3$, 
$56.1,65.8,123.4,125.4,126.0,126.7,127.4,128.5,139.4,140.4,143.3,173.58 ;$ HRMS [ESI]: $m / z$ calcd for $\mathrm{C}_{34} \mathrm{H}_{32} \mathrm{~N}_{2} \mathrm{O}_{4} \mathrm{Na}: 555.2259(\mathrm{M}+\mathrm{Na})^{+}$, found: 555.2255

\subsubsection{Bis[(2'-hydroxy-1'-(R)-phenylethyl)]-amido-9,10-dihydro-9,10-ethanoanthacene 6}

The product was synthesized from the cis-9,10-dihydro-9,10-ethanoanthacene dicarboxylic anhydride 5 (225mg, $0.9 \mathrm{mmol})$, (-)-(R)- phenylglycinol (156mg, $0.9 \mathrm{mmol})$ and $\mathrm{N}$ Ethoxycarbonyl-2-ethoxy-1,2-dihydroquinoline $(247 \mathrm{mg}, 1.0 \mathrm{mmol})$ in $10 \mathrm{ml}$ of $\mathrm{THF}$ at ambiante temperature for $48 \mathrm{~h}$. Purification by column chromatography (EtOAc-MeOH , 9:1) yielded a white solid $(185 \mathrm{mg}, 77 \%)$ : m.p. $=125-127{ }^{\circ} \mathrm{C} ;[\alpha]_{589}{ }^{20}=-73\left(c 0.82, \mathrm{CHCl}_{3}\right) ;{ }^{1} \mathrm{H}$ NMR (400 MHz, CDCl3): $\delta=3.12(\mathrm{dd}, \mathrm{J}=12.0,22.8 \mathrm{~Hz}, 2 \mathrm{H}), 3.23,3.26(2 \mathrm{~d}, \mathrm{~J}=6.8 \mathrm{~Hz}$, 1H), 3.57-3.63 (m 2H), 3.73, $3.75(2 \mathrm{~d}, \mathrm{~J}=3.6 \mathrm{~Hz}, 1 \mathrm{H}), 4.040(\mathrm{dd}, \mathrm{J}=7.2,14.4 \mathrm{~Hz}, 1 \mathrm{H}), 4.41$ (br s, 1H), $4.80(\mathrm{~m}, 1 \mathrm{H}), 4.90(\mathrm{~m}, 1 \mathrm{H}), 7.02-7.36(\mathrm{~m}, 18 \mathrm{H}) ;{ }^{13} \mathrm{C} \mathrm{NMR}\left(100 \mathrm{MHz}, \mathrm{CDCl}_{3}\right): \delta=$ $46.2,47.0,49.4,50.6,55.5,56.2,65.2,65.6123 .5,123.6,124.5,126.3,126.4,126.9,127.0$, $127.1,127.2,127.7,127.8,128.7,128.7,138.8,139.3,139.5,141.9,142.4,142.8,172.4$, 173.1; HRMS [ESI]: $m / z$ calcd for $\mathrm{C}_{34} \mathrm{H}_{32} \mathrm{~N}_{2} \mathrm{O}_{4} \mathrm{Na}$ : $555.22598(\mathrm{M}+\mathrm{Na})^{+}$, found: 555.2257.

4.3. General procedure of preparation of bis(oxazoline) 4a, 4a', 4b, 4c, 4d, 4e, 4e', 4f, and 7

Diethylaminosulfur trifluoride (2.2 equiv) was added dropwise to a cooled suspension ($\left.78^{\circ} \mathrm{C}\right)$ of the corresponding bis-hydroxyamide in dry $\mathrm{CH}_{2} \mathrm{Cl}_{2}(10 \mathrm{~mL} / \mathrm{mmol})$ under argon. After stirring for 3-5 h at the indicated temperature, anhydrous $\mathrm{K}_{2} \mathrm{CO}_{3}$ (3 equiv) was added and the reaction mixture was allowed to warm to room temperature. A saturated aqueous $\mathrm{NaHCO}_{3}$ solution was added and after phase separation the aqueous layer was extracted with $\mathrm{CH}_{2} \mathrm{Cl}_{2}$. After drying over $\mathrm{MgSO}_{4}$ and evaporation, the crude product was purified by column chromatography (Hexane-EtOAc). 


\subsection{1. (11S,12S)-Bis[(4'R)-phenyloxazoline]-9,10-dihydro-9,10-ethanoanthacene 4a}

The product was synthesized from $\mathbf{3 a}(0.7 \mathrm{~g}, 1.31 \mathrm{mmol})$ according to the general procedure described above Purification by column chromatography (hexane-EtOAc, 3:2) yielded a white solid (513 mg, 78\%): m.p. $=85-86{ }^{\circ} \mathrm{C} ;[\alpha]_{\mathrm{D}}{ }^{20}=+83\left(c 0.96, \mathrm{CHCl}_{3}\right) ;{ }^{1} \mathrm{H}$ NMR $(400 \mathrm{MHz}$, CDCl3): $\delta=3.68(\mathrm{~s}, 2 \mathrm{H}), 4.01(\mathrm{t}, \mathrm{J}=8.0 \mathrm{~Hz}, 2 \mathrm{H}), 4.57(\mathrm{t}, \mathrm{J}=9.2 \mathrm{~Hz}, 2 \mathrm{H}), 4.82(\mathrm{~s}, 2 \mathrm{H}), 5.01$ $(\mathrm{t}, \mathrm{J}=8.4 \mathrm{~Hz}, 2 \mathrm{H}), 7.08-7.27(\mathrm{~m}, 14 \mathrm{H}), 7.34,7.38(2 \mathrm{~d}, \mathrm{~J}=6.4 \mathrm{~Hz}, 4 \mathrm{H}) ;{ }^{13} \mathrm{C} \mathrm{NMR}(100 \mathrm{MHz}$, $\left.\mathrm{CDCl}_{3}\right): \delta=42.9,47.0,69.3,75.3,123.9,125.1,126.1,126.3,126.6,127.4,128.6,140.5$, 142.4, 142.5, 168.8; HRMS [ESI]: $m / z$ calcd for $\mathrm{C}_{34} \mathrm{H}_{29} \mathrm{~N}_{2} \mathrm{O}_{2}: 497.2229(\mathrm{M}+\mathrm{H})^{+}$, found: 497.2229.

\subsection{2. (11S,12S)-bis[(4'S)-phenyloxazoline]-9,10-dihydro-9,10-ethanoanthacene $4 a^{\prime}$}

The product was synthesized from 3a' $(0.50 \mathrm{~g}, 0.94 \mathrm{mmol})$ according to the general procedure described above. Purification by column chromatography (hexane-EtOAc, 3:2) yielded a white solid (300 mg, 68\%): m.p. $=177{ }^{\circ} \mathrm{C} ;[\alpha]_{\mathrm{D}}{ }^{20}=+31\left(c 0.87, \mathrm{CHCl}_{3}\right) ;{ }^{1} \mathrm{H} \mathrm{NMR}(400 \mathrm{MHz}$, $\mathrm{CDCl} 3): \delta=3.83(\mathrm{~s}, 2 \mathrm{H}), 3.86(\mathrm{t}, \mathrm{J}=8.0 \mathrm{~Hz}, 2 \mathrm{H}), 4.50(\mathrm{dd}, \mathrm{J}=8.4,10.0 \mathrm{~Hz}, 2 \mathrm{H}), 4.78(\mathrm{~s}$, 2H), $4.92(\mathrm{t}, \mathrm{J}=8.8 \mathrm{~Hz}, 2 \mathrm{H}), 6.40(\mathrm{~d}, \mathrm{~J}=8.4 \mathrm{~Hz}, 4 \mathrm{H}), 7.05-7.18(\mathrm{~m}, 12 \mathrm{H}), 7.23,7.36(2 \mathrm{~d}, \mathrm{~J}=$ $6.8 \mathrm{~Hz}, 4 \mathrm{H}) ;{ }^{13} \mathrm{C} \mathrm{NMR}\left(100 \mathrm{MHz}, \mathrm{CDCl}_{3}\right): \delta=43.1,46.5,69.1,75.9,124.5,124.9,126.3$, $126.3,126.4,127.2,128.4,140.9,142.0,142.1,169.2$; HRMS [ESI]: $\mathrm{m} / \mathrm{z}$ calcd for $\mathrm{C}_{34} \mathrm{H}_{29} \mathrm{~N}_{2} \mathrm{O}_{2}: 497.2229(\mathrm{M}+\mathrm{H})^{+}$, found: 497.2229

\subsection{3. (11S,12S)-Bis[(4'S)-isopropyloxazoline]-9,10-dihydro-9,10-ethanoanthacene 4b}

The product was synthesized from $\mathbf{3 b}(0.5 \mathrm{~g}, 1.0 \mathrm{mmol})$ according to the general procedure described above. Purification by column chromatography (hexane-EtOAc, 2:3) yielded a white solid (295 mg, 63\%): m.p. $=67-69^{\circ} \mathrm{C} ;[\alpha]_{\mathrm{D}}{ }^{20}=-11\left(c 0.52, \mathrm{CHCl}_{3}\right) ;{ }^{1} \mathrm{H} \mathrm{NMR}(400 \mathrm{MHz}$ , CDCl3): $\delta=0.65,0.71(2 \mathrm{~d}, \mathrm{~J}=6.8 \mathrm{~Hz}, 12 \mathrm{H}), 0.78,0.92(2$ quintuplets, $\mathrm{J}=7.2 \mathrm{~Hz}, 4 \mathrm{H}), 1.30$ ( septuplet, J = 6.8 Hz, 2H), $3.46(\mathrm{~s}, 2 \mathrm{H}), 3.69(\mathrm{t}, \mathrm{J}=7.2 \mathrm{~Hz}, 2 \mathrm{H}), 3.80$ (quintuplet, $\mathrm{J}=7.6 \mathrm{~Hz}$, 
2H), $4.13(\mathrm{t}, \mathrm{J}=8.0 \mathrm{~Hz}, 2 \mathrm{H}), 4.60(\mathrm{~s}, 2 \mathrm{H}), 6.97-7.05(\mathrm{~m}, 4 \mathrm{H}) ; 7.13,7.27(2 \mathrm{~d}, \mathrm{~J}=6.8 \mathrm{~Hz}, 4 \mathrm{H})$;

${ }^{13} \mathrm{C} \mathrm{NMR}\left(100 \mathrm{MHz}, \mathrm{CDCl}_{3}\right): \delta=22.6,22.7,24.9,42.3,45.8,46.9,64.0,73.4,124.0,124.6$, 125.8, 126.1, 140.6, 141.8, 166.9; HRMS [ESI]: $m / z$ calcd for $\mathrm{C}_{30} \mathrm{H}_{37} \mathrm{~N}_{2} \mathrm{O}_{2}$ : 457.2855, $(\mathrm{M}+\mathrm{H})^{+}$, found: 457.2857 .

\subsection{4. (11S,12S)-Bis[(4'S)-tert-butyloxazoline]-9,10-dihydro-9,10-ethanoanthacene 4c}

The product was synthesized from $3 \mathrm{c}(0.5 \mathrm{~g}, 1.02 \mathrm{mmol})$ according to the general procedure described above. Purification by column chromatography (hexane-EtOAc, 3:1) yielded a white solid (404 mg, 86\%): m.p. $=84-86{ }^{\circ} \mathrm{C} ;[\alpha]_{\mathrm{D}}{ }^{20}=-19\left(c 0.51, \mathrm{CHCl}_{3}\right) ;{ }^{1} \mathrm{H}$ NMR $(400$ $\mathrm{MHz}, \mathrm{CDCl} 3): \delta=3.56(\mathrm{~s}, 2 \mathrm{H}), 3.59(\mathrm{t}, \mathrm{J}=9.2 \mathrm{~Hz}, 2 \mathrm{H}), 3.86(\mathrm{t}, \mathrm{J}=8.4 \mathrm{~Hz}, 2 \mathrm{H}), 4.07(\mathrm{t}, \mathrm{J}=$ $8.4 \mathrm{~Hz}, 2 \mathrm{H}), 4.60(\mathrm{~s}, 2 \mathrm{H}), 6.92,6.98(2 \mathrm{t}, \mathrm{J}=7.2 \mathrm{~Hz}, 4 \mathrm{H}), 7.10,7.23(2 \mathrm{~d}, \mathrm{~J}=7.2 \mathrm{~Hz}, 4 \mathrm{H}) ;{ }^{13} \mathrm{C}$ NMR (100 MHz, $\left.\mathrm{CDCl}_{3}\right): \delta=25.6,32.9,43.0,46.5,69.1,75.3,123.7,124.9,125.97,126.0$, 140.8, 142.3, 167.2; HRMS [ESI]: $m / z$ calcd for $\mathrm{C}_{30} \mathrm{H}_{37} \mathrm{~N}_{2} \mathrm{O}_{2}: 457.2855(\mathrm{M}+\mathrm{H})^{+}$, found:457.2855.

\subsection{5. (11S,12S)-Bis(oxazoline)-9,10-dihydro-9,10-ethanoanthacene 4d}

The bis(hydroxyamide) $\mathbf{3 d}(250 \mathrm{mg}, 0.66 \mathrm{mmol})$ in $\mathrm{CH}_{2} \mathrm{Cl}_{2}(5 \mathrm{ml})$ was treated with $\mathrm{SOCl}_{2}$ (1.56 $\mathrm{g}, 13.1 \mathrm{mmol})$. After $15 \mathrm{~min}$, the solution was heated at reflux for $3 \mathrm{~h}$, then recooled to room temperature and washed sequentially with cold water $(10 \mathrm{ml}), 0.1 \mathrm{M} \mathrm{K}_{2} \mathrm{CO}_{3}(2 \times 10 \mathrm{ml})$, and saturated aqueous $\mathrm{NaCl}(10 \mathrm{ml})$. After drying over $\mathrm{MgSO}_{4}$ and evaporation, the crude bisamide dichloride was obtained as a white solid (175 mg, 93\%): ${ }^{1} \mathrm{H}$ NMR (400 MHz , $\mathrm{CDCl} 3): \delta=2.84(\mathrm{~s}, 2 \mathrm{H}), 3.45(\mathrm{~m}, 8 \mathrm{H}), 4.55(\mathrm{~s}, 2 \mathrm{H}), 7.04-7.11(\mathrm{~m}, 4 \mathrm{H}), 7.24,7.29(2 \mathrm{~d}, \mathrm{~J}=$ $6.4 \mathrm{~Hz}, 4 \mathrm{H})$. HRMS [ESI]: $\mathrm{m} / z$ calcd for $\mathrm{C}_{22} \mathrm{H}_{22} \mathrm{~N}_{2} \mathrm{O}_{2} \mathrm{Cl}_{2} \mathrm{Na}: 439.0956(\mathrm{M}+\mathrm{Na})^{+}$, found: 439.0957.

A mixture of the crude bisamide dichloride, $170 \mathrm{mg}(0.41 \mathrm{mmol})$, and $\mathrm{NaOH}(500 \mathrm{mg}, 30$ mmol) in 50\% aqueous $\mathrm{MeOH}(5 \mathrm{ml})$ was heated under reflux for 4 hours. After cooling, the 
mixture was extracted with $\mathrm{CH}_{2} \mathrm{CL}_{2}$ and washed with saturated aqueous $\mathrm{NaCl}$. Column chromatography on silica (EtOAc/MeOH, 9:1) yielded the ligand 4d as a white solid (102 mg, $73 \%):$ m.p. $=95-98{ }^{\circ} \mathrm{C} ;, 0.102 \mathrm{~g}(73 \%) .[\alpha]_{\mathrm{D}}{ }^{20}=+34\left(c 1.23, \mathrm{CHCl}_{3}\right) ;{ }^{1} \mathrm{H}$ NMR $(400 \mathrm{MHz}$, $\left.\mathrm{CDCl}_{3}\right): \delta=3.38(\mathrm{~s}, 2 \mathrm{H}), 3.44-3.64(\mathrm{~m}, 4 \mathrm{H}), 4.06-4.16(\mathrm{~m}, 4 \mathrm{H}), 4.62(\mathrm{~s}, 2 \mathrm{H}), 6.99-7.05(\mathrm{~m}$, 4H), 7.15, $7.25(2 \mathrm{~d}, \mathrm{~J}=6.4 \mathrm{~Hz}, 4 \mathrm{H}) ;{ }^{13} \mathrm{C} \mathrm{NMR}\left(100 \mathrm{MHz}, \mathrm{CDCl}_{3}\right): \delta=42,7,46.9,54.1,67.8$, 123.8, 124.7, 126.0, 126.2, 140,4, 142.3, 168.4; HRMS [ESI]: $m / z$ calcd for $\mathrm{C}_{22} \mathrm{H}_{21} \mathrm{~N}_{2} \mathrm{O}_{2}$ : $345.1603(\mathrm{M}+\mathrm{H})^{+}$, found: 345.1611.

\subsection{6. (11R,12R)-Bis[(4'S)-phenyloxazoline]-9,10-dihydro-9,10-ethanoanthacene $4 \mathrm{e}$}

The product was synthesized from $3 \mathbf{e}(0.5 \mathrm{~g}, 0.94 \mathrm{mmol})$ according to the general procedure described above. Purification by column chromatography (hexane-EtOAc, 3:2) yielded a white solid (440 mg, 68\%): m.p. $=81-82{ }^{\circ} \mathrm{C} ;[\alpha]_{\mathrm{D}}{ }^{20}=-82\left(c 0.65, \mathrm{CHCl}_{3}\right) ;{ }^{1} \mathrm{H} \mathrm{NMR}(400 \mathrm{MHz}$ , $\mathrm{CDCl} 3): \delta=3.58(\mathrm{~s}, 2 \mathrm{H}), 3.92(\mathrm{t}, \mathrm{J}=8.0 \mathrm{~Hz}, 2 \mathrm{H}), 4.48(\mathrm{t}, \mathrm{J}=8.4 \mathrm{~Hz}, 2 \mathrm{H}), 4.72(\mathrm{~s}, 2 \mathrm{H})$, $54.90(\mathrm{t}, \mathrm{J}=8.0 \mathrm{~Hz}, 2 \mathrm{H}), 6.96-7.18(\mathrm{~m}, 14 \mathrm{H}), 7.24,7.28(2 \mathrm{~d}, \mathrm{~J}=6.4 \mathrm{~Hz}, 4 \mathrm{H}) ;{ }^{13} \mathrm{C} \mathrm{NMR}(100$ $\left.\mathrm{MHz}, \mathrm{CDCl}_{3}\right): \delta=43,146.5,69.1,75.9,124.5,124.9,126.3,126.3,126.4,127.2,128.4$, 140.9, 142.0, 142.1, 169.2; HRMS [ESI]: $m / z$ calcd for $\mathrm{C}_{34} \mathrm{H}_{29} \mathrm{~N}_{2} \mathrm{O}_{2}: 497.2229(\mathrm{M}+\mathrm{H})^{+}$, found: 497.2229.

\subsection{7. (11R,12R)-Bis[(4'R)-phenyloxazoline]-9,10-dihydro-9,10-ethanoanthacene $4 \mathrm{e}^{\prime}$}

The product was synthesized from $3 \mathbf{e}^{\prime}(0.5 \mathrm{~g}, 0.94 \mathrm{mmol})$ according to the general procedure described above. Purification by column chromatography (hexane-EtOAc, 3:2) yielded a white solid (407 mg, 63\%): m.p. $=178{ }^{\circ} \mathrm{C} ;[\alpha]_{\mathrm{D}}{ }^{20}=-33\left(c 0.87, \mathrm{CHCl}_{3}\right) ;{ }^{1} \mathrm{H} \mathrm{NMR}(400 \mathrm{MHz}$, $\mathrm{CDCl} 3): \delta=3.83(\mathrm{~s}, 2 \mathrm{H}), 3.87(\mathrm{t}, \mathrm{J}=8.0 \mathrm{~Hz}, 2 \mathrm{H}), 4.50(\mathrm{dd}, \mathrm{J}=8.4,10.0 \mathrm{~Hz}, 2 \mathrm{H}), 4.78(\mathrm{~s}$, 2H), $4.92(\mathrm{t}, \mathrm{J}=8.8 \mathrm{~Hz}, 2 \mathrm{H}), 6.41(\mathrm{~d}, \mathrm{~J}=7.2 \mathrm{~Hz}, 4 \mathrm{H}), 7.05-7.18(\mathrm{~m}, 10 \mathrm{H}), 7.23,7.36(2 \mathrm{~d}, \mathrm{~J}=$ $6.8 \mathrm{~Hz}, 4 \mathrm{H}) ;{ }^{13} \mathrm{C} \mathrm{NMR}\left(100 \mathrm{MHz}, \mathrm{CDCl}_{3}\right): \delta=43.1,46.5,69.1,75.9,124.5,124.9,126.3$, 
$126.3,126.4,127.2,128.4,140.9,142.0,142.1,169.2$; HRMS [ESI]: $\mathrm{m} / \mathrm{z}$ calcd for $\mathrm{C}_{34} \mathrm{H}_{29} \mathrm{~N}_{2} \mathrm{O}_{2}: 497.2229(\mathrm{M}+\mathrm{H})^{+}$, found: 497.2229.

\subsection{8.(11S,12S+11R,12R)-Bis[(4'R)-phenyloxazoline]-9,10-dihydro-9,10-ethanoanthacene $4 f$}

The product was synthesized from $3 \mathbf{f}(0.5 \mathrm{~g}, 0.94 \mathrm{mmol})$ according to the general procedure described above. Purification by column chromatography (hexane-EtOAc, 3:2) yielded a white solid (230 mg, 52\%): m.p. $=91-95{ }^{\circ} \mathrm{C} ;[\alpha]_{\mathrm{D}}{ }^{20}=+13\left(c 10, \mathrm{CHCl}_{3}\right) ;{ }^{1} \mathrm{H} \mathrm{NMR}(400 \mathrm{MHz}$, $\mathrm{CDCl} 3): \delta=3.58(\mathrm{~s}, 2 \mathrm{H}), 3.83(\mathrm{~s}, 2 \mathrm{H}), 3.87,3.91(2 \mathrm{t}, \mathrm{J}=8.0 \mathrm{~Hz}, 4 \mathrm{H}), 4.45-4.53(\mathrm{~m}, 4 \mathrm{H})$, $4.72(\mathrm{~s}, 2 \mathrm{H}), 4.78(\mathrm{~s}, 2 \mathrm{H}), 4.87-4.95(\mathrm{~m}, 4 \mathrm{H}), 6.41(\mathrm{~d}, \mathrm{~J}=6.0 \mathrm{~Hz}, 4 \mathrm{H}), 6.96-7.37(\mathrm{~m}, 32 \mathrm{H})$; ${ }^{13} \mathrm{C} \mathrm{NMR}\left(100 \mathrm{MHz}, \mathrm{CDCl}_{3}\right): \delta=42.8,43.1,46.5,47.0,69.1,69.2,75.3,75.9,123.8,124.5$, $124.8,125.1,126.1,126.2,126.3,126.3,126.4,126.5,127.2,127.4,128.4,128.5,140.4$, 140.9, 142.1, 142.3, 142.5, 168.8, 169.2; HRMS [ESI]: calcd for $\mathrm{C}_{34} \mathrm{H}_{29} \mathrm{~N}_{2} \mathrm{O}_{2}$ : 497.2229 $(\mathrm{M}+\mathrm{H})^{+}$, found: 497.2229 .

\subsubsection{Bis[(4'R)-phenyloxazoline]-9,10-dihydro-9,10-ethanoanthacene 7}

The product was synthesized from $6(0.3 \mathrm{~g}, 0.56 \mathrm{mmol})$ according to the general procedure described above. Purification by column chromatography (hexane-EtOAc, 3:2) yielded a white solid (90 mg, 54\%): m.p. $\left.=60-62{ }^{\circ} \mathrm{C} ;[\alpha]_{\mathrm{D}}{ }^{20}=+43, c 0.58, \mathrm{CHCl}_{3}\right) ;{ }^{1} \mathrm{H} \mathrm{NMR}(400 \mathrm{MHz}$ , CDCl3): $\delta=3.18(\mathrm{~d}, \mathrm{~J}=10.8 \mathrm{~Hz}, 1 \mathrm{H}), 3.35(\mathrm{t}, \mathrm{J}=8.4 \mathrm{~Hz}, 1 \mathrm{H}), 3.43(\mathrm{~d}, \mathrm{~J}=8.4 \mathrm{~Hz}, 1 \mathrm{H}), 3.54$ $(\mathrm{dd}, \mathrm{J}=2.0,10.8 \mathrm{~Hz}, 1 \mathrm{H}), 4.04,4.07(2 \mathrm{~d}, \mathrm{~J}=8.4 \mathrm{~Hz}, 1 \mathrm{H}), 4.29,4.31(2 \mathrm{~d}, \mathrm{~J}=8.4 \mathrm{~Hz}, 1 \mathrm{H})$, $4.56(\mathrm{~d}, \mathrm{~J}=2 \mathrm{~Hz}, 1 \mathrm{H}), 4.81(\mathrm{~s}, 1 \mathrm{H}), 4.93(\mathrm{t}, \mathrm{J}=9.2 \mathrm{~Hz}, 2 \mathrm{H}), 5.03(\mathrm{t}, \mathrm{J}=9.4 \mathrm{~Hz}, 1 \mathrm{H}), 6.84-7.25$ $(\mathrm{m}, 17 \mathrm{H}), 7.42-7.44(\mathrm{~m}, 1 \mathrm{H}) .{ }^{13} \mathrm{C}$ NMR $\left(100 \mathrm{MHz} \mathrm{CDCl}_{3}\right): \delta=41.6,41.7,46.5,48.8,69.0$, 69.1, 74.6, 74.8, 123.5, 124.0, 124.6, 125.7, 126.3, 126.4, 126.5, 126.7, 126.9, 127.1, 127.3, 128.4 128.6, 140.7, 141.2, 142.3, 142.4, 142.6, 143.7, 168.0, 168.2. HRMS [ESI]: $\mathrm{m} / z$ calcd for $\mathrm{C}_{34} \mathrm{H}_{29} \mathrm{~N}_{2} \mathrm{O}_{2}: 497.2229(\mathrm{M}+\mathrm{H})^{+}$, found: 497.2229. 


\subsection{General procedure for asymmetric Diels-Alder reaction}

A mixture of $\mathrm{Cu}(\mathrm{II})(\mathrm{OTf})_{2}(5 \mu \mathrm{mol}, 10 \mathrm{~mol} \%)$ and the ligand $4(6 \mu \mathrm{mol}$,$) in dry \mathrm{CH}_{2} \mathrm{Cl}_{2}(0.2$ $\mathrm{ml})$ was stirred for $0.5 \mathrm{~h}$ at room temperature under argon. The dienophile $(50 \mu \mathrm{mol}$ in $50 \mu \mathrm{l}$ $\left.\mathrm{CH}_{2} \mathrm{Cl}_{2}\right)$ and freshly distilled cyclopentadiene $(150 \mu \mathrm{mol})$ were then respectively added. The reaction was monitored by TLC and stopped after consumption of the starting substrate. The reaction mixture was purified on silica gel with hexane-ethyl acetate $(3: 1)$ to give a mixture of endo and exo isomers of cycloadducts 9 . The yield was calculated on the basis of the isolated products. The endolexo ratio was determined by ${ }^{1} \mathrm{H}$ NMR analysis and confirmed by HPLC analysis. The enantiomeric excess of the cycloadduct was determined by chiral HPLC analysis: Daicel Chiralcel OD-H column, hexane- $i-\mathrm{PrOH}, 95: 5$, flow rate $=1 \mathrm{ml} / \mathrm{min}$, detection: $220 \eta \mathrm{m}$. The absolute configuration of the cycloadduct endo-9 product was assigned based upon the comparison of the sign of optical rotation with the literature values: (+) for (R)-9 and (-) for (S)-9.

\section{Supplementary data}

Copies of ${ }^{1} \mathrm{H}$ and ${ }^{13} \mathrm{C}$ NMR spectra of bis(hydroxyamide) $\mathbf{3 a}, \mathbf{3 a}, \mathbf{3 b}, \mathbf{3 c}, \mathbf{3 d}, \mathbf{3 e}, \mathbf{3 e}, \mathbf{3}$ and

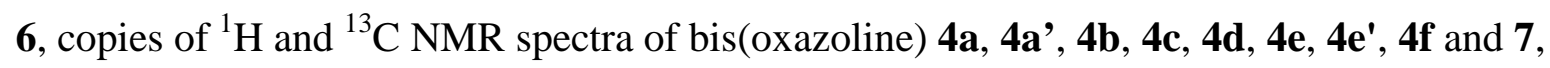
HPLC chromatograms of selected Diels-alder reactions, X-ray crystallographic data of ligand 4a.

\section{Legends}

Fig. 1. Structure of various chiral bis(oxazoline) ligands linked with a rigid backbone.

Fig. 2. ${ }^{1} \mathrm{H}$ NMR study of the epimerization of ligand 7 in $\mathrm{CDCl}_{3}$

(A) After purification; Time: $1 \mathrm{~h}$ 
(B) Time: $24 \mathrm{~h}$

(C) Time: $48 \mathrm{~h}$

Fig. 3. ORTEP drawing and atom labeling of ligand 4a

Fig. 4. $\mathrm{Cu}(\mathrm{II})$-complexes of the four diastereomeric ligands 4 and the correlation between structure of the ligand and configuration of the cycloadduct

Scheme 1. Synthesis of different chiral bis(oxazoline) with a dihydroethanoanthracene backbone.

\section{References and notes}

1. Bolm, C. Angew. Chem. Int. Ed. 1991, 30, 542-543.

2. Pfaltz, A. Acc. Chem. Res. 1993, 26, 339-345.

3. Ghosh, A. K.; Mathivanan, P.; Cappiello, J. Tetrahedron Asymmetry 1998, 9, 1-45.

4. Rechavi, D.; Lemaire, M. Chem. Rev. 2002, 102, 3467-3494.

5. $\quad$ McManus, H. A.; Guiry, P. J. Chem. Rev. 2004, 104, 4151-4202.

6. Desimoni, G.; Faita, G.; Jørgensen, K. A. Chem. Rev. 2006, 106, 3561-3651.

7. Fraile, J. M.; García, J. I.; Mayoral, J. A. Coord. Chem. Rev. 2008, 252, 624-646.

8. Reymond, S.; Cossy, J. Chem. Rev. 2008, 108, 5359-5406.

9. Desimoni, G.; Faita, G.; Jørgensen, K. A. Chem. Rev. 2011, 111, PR284-PR437.

10. Imai, Y.; Zhang, W.; Kida, T.; Nakatsuji, Y.; Ikeda, I. Tetrahedron Asymmetry 1996, 7, 2453-2462.

11. Bedekar, A. V.; Andersson, P. G. Tetrahedron Lett. 1996, 37, 4073-4076.

12. Bedekar, A. V.; Koroleva, E. B.; Andersson, P. G. J. Org. Chem. 1997, 62, 25182526.

13. Takacs, J. M.; Quincy, D. A.; Shay, W.; Jones, B. E.; Ross II, C. R. Tetrahedron Asymmetry 1997, 8, 3079-3087.

14. Kato, K.; Tanaka, M.; Yamamura, S.; Yamamoto, Y.; Akita, H. Tetrahedron Lett. 2003, 44, 3089-3092.

15. Ma, L.; Du, D.-M.; Xu, J. J. Org. Chem. 2005, 70, 10155-10158.

16. Atodiresei, I.; Schiffers, I.; Bolm, C. Tetrahedron Asymmetry 2006, 17, 620-633.

17. Corey, E. J.; Imai, N.; Zhang, H. Y. J. Am. Chem. Soc. 1991, 113, 728-729.

18. Corey, E. J.; Ishihara, K. Tetrahedron Lett. 1992, 33, 6807-6810.

19. Evans, D. A.; Chapman, K. T.; Bisaha, J. J. Am. Chem. Soc. 1988, 110, 1238-1256.

20. Evans, D. A.; Miller, S. J.; Lectka, T. J. Am. Chem. Soc. 1993, 115, 6460-6461.

21. Evans, D. A.; Murry, J. A.; von Matt, P.; Norcross, R. D.; Miller, S. J. Angew. Chem. Int. Ed. 1995, 34, 798-800.

22. Evans, D. A.; Kozlowski, M. C.; Tedrow, J. S. Tetrahedron Lett. 1996, 37, 7481-7484.

23. Evans, D. A.; Miller, S. J.; Lectka, T.; von Matt, P. J. Am. Chem. Soc. 1999, 121, 7559-7573. 
24. Evans, D. A.; Barnes, D. M.; Johnson, J. S.; Lectka, T.; von Matt, P.; Miller, S. J.; Murry, J. A.; Norcross, R. D.; Shaughnessy, E. A.; Campos, K. R. J. Am. Chem. Soc. 1999, 121, 7582-7594.

25. Evans, D. A.; Tomislaw, R.; S., J. J. Pure Appl. Chem. 1999, 71, 1407-1415.

26. Johannsen, M.; Jørgensen, K. A. J. Org. Chem. 1995, 60, 5757-5762.

27. Desimoni, G.; Faita, G.; Righetti, P. P. Tetrahedron Lett. 1996, 37, 3027-3030.

28. Desimoni, G.; Faita, G.; Toscanini, M.; Boiocchi, M. Chem. Eur. J. 2009, 15, 96749677.

29. Ghosh, A. K.; Mathivanan, P.; Cappiello, J. Tetrahedron Lett. 1996, 37, 3815-3818.

30. Davies, I. W.; Gerena, L.; Cai, D.; Larsen, R. D.; Verhoeven, T. R.; Reider, P. J. Tetrahedron Lett. 1997, 38, 1145-1148.

31. Takacs, J. M.; Lawson, E. C.; Michael Reno, J.; Youngman, M. A.; Quincy, D. A. Tetrahedron Asymmetry 1997, 8, 3073-3078.

32. Brienne, M.-J.; Jacques, J. Bull. Soc. Chim. Fr. 1973, 190-197.

33. Bachmann, W. E.; Scott, L. B. J. Am. Chem. Soc. 1948, 70, 1458-1461.

34. Belleau, B.; Malek, G. J. Am. Chem. Soc. 1968, 90, 1651-1652.

35. Crystal structure data deposited at the Cambridge Crystallographic Data Centre with deposit number CCDC 935282. 